\title{
WHO：国際化学物質安全性計画 IPCS*
}

森本和滋

\section{1.はじめに}

現在, 地球上に存在する化学物質の総数は約 1 千万 といわれ，そのうち10万が地球規模で大量に使用され ている。さらに毎年新しく商品として市場に登場する 化学物質の数は千〜 2 千と推定されている1)。これら 化学物質による恩恵を受けながら，他方では健康影響 や環境影響を危惧しながら宇宙船 “地球号”はその営 みを続けている。

IPCS は国際化学物質安全性計画と呼ばれ，化学物 質のこのような使用の拡大に対応してヒトの健康やそ の地球環境問題となる影響を科学的な基盤に立って評 価し，対処することを目的として国連環境計画 (UNEP, United Nations Environment Programme), 国際労働機関 (ILO, International Labour Office）および世界保健機関（WHO, World Health Organization）の共同事業として1980年に発足した。 本稿では IPCS を通じての化学物質の安全性評価に関 する国際協力と情報管理について紹介する。

\section{IPCS 設立までの化学物質安全性の歴史}

昨年11月東京で, IPCS 発足およびわが国の IPCS へ の協力 10 年を記念して WHO/IPCS マネージャーM. Mercier 博士を招いて「IPCS の活動と展望」について 講演会を開催した。IPCS の設立までの化学物質の安 全性管理の歴史を振り返ると，ILO が1921年に化学的 な取り決めに関する会議を開いたのが最初の国際的な 協力であり，1957年国連は化学製品の貿易が増大する ことに伴う運搬の際の安全性が重要と考え，危険物の

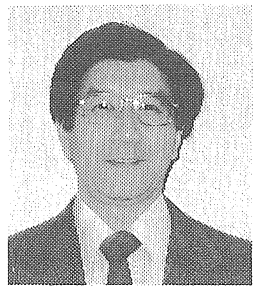

Kazushige Morimoto

昭和 47 年 大阪大学薬学部修士課程了

48年 国立公衆衛生院専攻課程環 境科学科了

62 年 国立衛生試験所医化学部室 長

平成元年 同上化学物質情報部室長 薬学博士

〔趣 味〕ジョギング，映画鑑賞

* WHO : International Programme on Chemical Safety, 1991年 4 月11日受理
運搬に関する勧告作業を開始した。1960年代には化学 物質による環境污染が問題となり,FAO, WHO, ILO, および経済協力開発機構（The Organization for Economic Cooperation and Development, OECD) 等の 国際機関が益々悪化する環境污染をコントロールすべ くそれぞれの活動を開始した。また，1962年国連食糧 農業機関(FAO, Food and Agriculture Organization) とWHO が, 食品の安全性と食品添加物や食品中に混 入する化学物質から消費者の健康を保護することを旨 として国際食品規格委員会 (Codex Alimentarius Commission)を組織した。1972年にはストックホルム で国連人間環境会議が開催され『人間環境宣言』が採 択され，地球レベルで人間の住む環境をより安全によ り快適にするため国連が本格的に取り組む姿勢を明確 に示した。この宣言を受けて翌73年 UNEP が設立さ れ, WHO も同年環境保健基準計画を開始し化学物質 が人体に直接または環境経由で及ぼす健康影響につい て総合的に評価する仕事を始めた。ILO も労衝衛生や 安全性に関する分野に力点を置きまた OECD は化学 物質の管理に関する指導と合意について独自の計画を 開始した。このように国際機関が個別にばらばらに 行っていた活動を調整する目的で1980年に IPCS が設 立された。IPCS の執行機関であるセントラルユニッ トはスイスのジュネーブにある WHO 環境保健部に 置かれており，わが国は直ちにこれに参加し国立衛生 試験所が参加機関 (National Participating Institutions, PI's) としての指名を受けた。従って我々の研究 所も IPCS と共に10年の歩みを終えたことになる。

\section{IPCS の目的と事業}

IPCS の目的は化学物質の安全性に関した活動の活 性化とその調整を国際的に行うことにある。最近 IPCS 事務局より 10 周年を記念して，「化学物質の安全 性の 10 年」との小冊子 ${ }^{11}$ が送られてきた。化学物質の安 全性の評価には，環境への影響を生態系への様々な有 害性から評価すること，ヒトの健康への有害性を保健 衛生や毒性の面から評価すること，さらにヒトの健康 への有害性を労働衛生や産業医学の面加とらえるこ と等多方面にわたる学際的協力が必要である。IPCS は30力国以上の協力と様々な国際機関の連携したプロ 


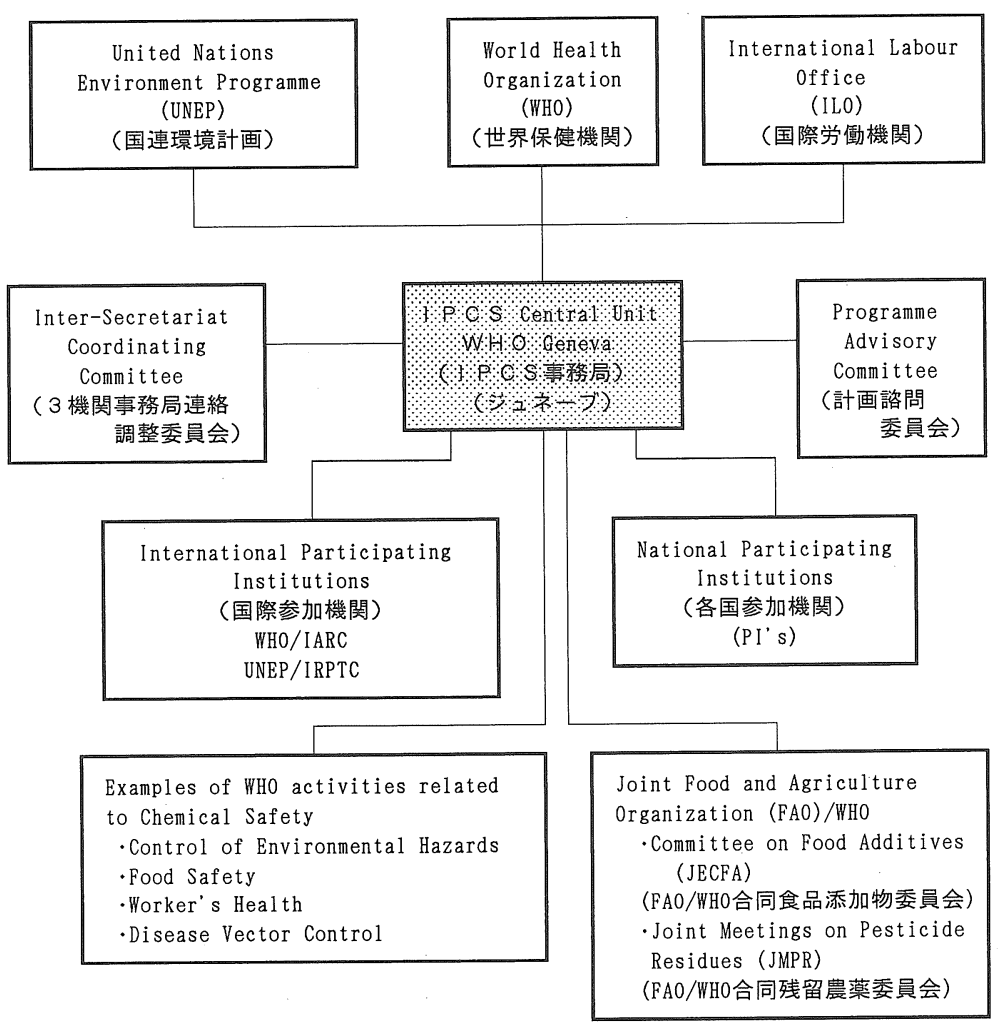

図 1 IPCS組織図

グラムであり (図 1 )，得られた情報を有効に調整し整 理統括していくことが大きな使命である。従ってこの 10年の歩みもまさに国際協力の歴史であった。

IPCS には下記のような 6 つの事業がある。

(1)さまざまな形態で存在する化学物質（工業化学 物質，農業，食品添加物，金属，その他）や物理的因 子（紫外線，超音波，磁場等）および生物的因子（力 ビ毒，植物アルカロイド）の曝露によるヒトの健康や 環境への危険度（リスク）を評価し，その結果を広く 刊行する。

(2) 化学物質の曝露によるヒトの健康や環境への危 険度と有毒性を評価するための各種試験法の開発（毒 性, 生態影響, 疫学, その他), 改善とその利用の促進。

(3) 加盟国，とくに発展途上国との技術協力の推進

(4) 化学物質による事故や災害（緊急事態）に効果 的に対応するための国際協力を促進する。

(5) 化学物質による中毒の予防と治療に対する国家 レベルの計画を支援する。

(6) 人材養成のための教育訓練を促進する。

\section{IPCS の成果一兴の具体例について}

この 10 年間の様々な活動によって得られた具体的な
成果は世界中に広く提供されており，以下紹介する出 版物 ${ }^{2)}$ は丸善を通して購入できる。

\section{1 リスクアセスメントに関する出版物}

1) 環境保健クライテリア一Environmental Health Criteria, EHC

化学物質の安全性評価の参考となる科学的データ (おもに学術文献)を網羅的に収集, 評価し一冊の本に まとめたもの $(100$ ～200ページ)。安全性評価のための 方法論についても検討しまとめあげている。その発刊 リストを表 1 に示した。1976年に発行を開始し，年間 10〜20件作成されており,現在 116 冊まで出版されてい る。わが国で作成したものは13冊あり表 1 にマークを つけた。対象は化学物質の安全性評価に関心を持つ研 究者，行政官，産業界の人々である。

2 ) 安全衛生ガイドーHealth and Safety Guide, HSGS

化学物質の安全性について参考となる，事故防止， 中毒対策，各国の規制值等のデータを約20ページの簡 潔な体裁に要約したもので，1987年より発行を開始し た。対象は化学物質の安全性業務に携わる行政官，産 業界の人々である。わが国ではトリス一BP（Tris 一BP）の作成に寄与した。 
表 1 環境保健クライテリア（EHC）出版物リスト

網掛けは方法論

\begin{tabular}{|c|c|c|c|}
\hline 1 & 水銀 & 60 & 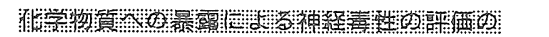 \\
\hline 2 & ポリ塩化ビフェニルとポリ塩化ターフェニル & & 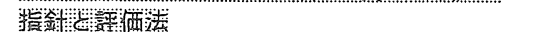 \\
\hline 3 & 鉛 & 61 & クロム \\
\hline 4 & 窒素酸化物 & 62 & 1,2-ジクロロエタン \\
\hline 5 & 硝酸、垔硝酸とN-ニトロソ化合物 & 63 & 有機リン系殺虫剂一概論 \\
\hline 6 & 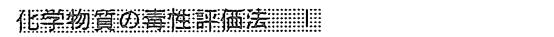 & 64 & カーバメート系農薬ー概論 \\
\hline 7 & 光化学オキシダント & 65 & ブタノール \\
\hline 8 & 硫黄酸化物と粉じん & 66 & ケレバン \\
\hline 9 & D D T とその代謝物 & 67 & テトラジフォン \\
\hline 10 & 二硫化崖素 & 68 & ヒドラジン \\
\hline 11 & かひ毒 & 69 & 磁場 \\
\hline 12 & 騒音 & 70 & 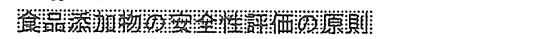 \\
\hline 13 & 一酸化岸素 & 71 & ベンタクロロフェノール \\
\hline 14 & 紫外線 & 72 & 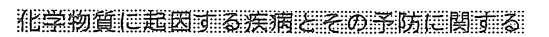 \\
\hline 15 & ススと有機スズ化合物 & & 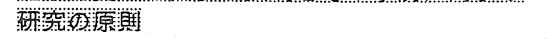 \\
\hline 16 & 無線周波とマイクロ波 & 73 & ホスフィンと金属リン化物 \\
\hline 17 & マンガン & 74 & ジアミノトルエン \\
\hline 18 & ヒ素 & 75 & トルエンジイソシアネート \\
\hline 19 & 硫化水素 & 76 & チオカーパメート系農薬ー概論 \\
\hline 20 & いくつかの石油製品 & 77 & 人造鉱物繊維 \\
\hline 21 & 塭素と塩化水素 & 78 & ジチオカーパメート系農薬 \\
\hline 22 & 超音波 & (2) 79 & ジクロルボス \\
\hline 23 & レーザーと光照射 & 80 & ピロリジジンアルカロイド \\
\hline 24 & チタン & 81 & バナジゥム \\
\hline 25 & いくつかの放射性同位元素 & (0) 82 & サイパーメスリン \\
\hline 26 & スチレン & 83 & D D T とその代謝物* \\
\hline 27 & 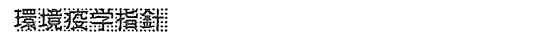 & 84 & 2,4-ジクロロフェノキシ酢酸* \\
\hline 28 & アクリロニトリル & 85 & 鉛* \\
\hline 29 & 2,4-ジクロロフェノキシ酢酸 $(2,4-D)$ & 86 & *は環境データのみ \\
\hline \multirow[t]{2}{*}{30} & 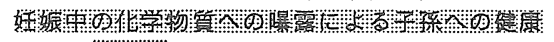 & (0) 87 & アレスリン \\
\hline & 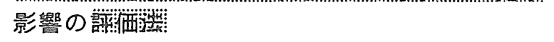 & 88 & ポリ塩化ジベンソパラダイオキシンとポリ塩化 \\
\hline 31 & テトラクロロエチレン & & ジベンソフフラン \\
\hline 32 & 塩化メチレン & 89 & ホルムアルデヒド \\
\hline 33 & エピクロロヒドリン & 90 & ジメトエート \\
\hline 34 & クロルデン & 91 & アルドリンとディルドリン \\
\hline 35 & 極低周波 & () 92 & レスメスリン \\
\hline 36 & フッ素 & 93 & クロロフェノール \\
\hline 37 & 淡水性およひ海水性生物の毒性 & (0) 94 & パーメスリン \\
\hline 38 & ヘプタクロル & (-) 95 & フェンパレレート \\
\hline 39 & パラコートとジクワット & (0) 96 & $d$ 一ーフェノスリン \\
\hline 40 & エンドスルファン & (0) 97 & デルタメスリン \\
\hline 41 & キントゼン & (0) 98 & テトラメスリン \\
\hline 42 & テクナゼン & 99 & サイハロスリン \\
\hline 43 & クロルデコン & 100 & ビニリデンクロライド \\
\hline 44 & マイレックス & 101 & メチル水銀 \\
\hline 45 & カンフェクロール & 102 & 1 ープロパノール \\
\hline 46 & 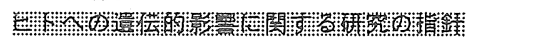 & 103 & 2 -プロパノール \\
\hline 47 & 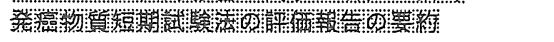 & 104 & 洹: \\
\hline 48 & ジメチル硫酸 & (0) 105 & マイコトキシン \\
\hline 49 & アクリルアミド & 106 & ベリリウム \\
\hline 50 & トリクロロエチレン & 107 & パリウム \\
\hline \multirow[t]{2}{*}{51} & 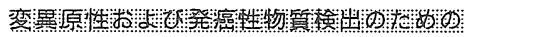 & 108 & ニッケル \\
\hline & 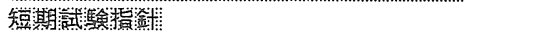 & 109 & 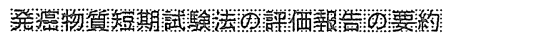 \\
\hline 52 & トルエン & (2) 110 & リン酸トリクレジル \\
\hline 53 & アスベストと天然鉱物織維 & (2) 111 & リン酸トリフェニル \\
\hline 54 & アンモニア & (2) 112 & リン酸トリブチル \\
\hline 55 & エチレンオキサイド & 113 & クロロフルオロカーボン(fully halogenated) \\
\hline 56 & プロピレンオキサイド & 114 & ジメチルホルムアミド \\
\hline 57 & 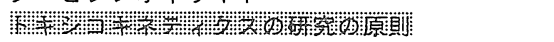 & 115 & 2 ーメトキシェタノールと 2 ーエトキシェタ \\
\hline 58 & セレン & & ノール及びそのアセテート \\
\hline 59 & 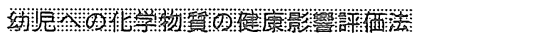 & 116 & トリブチルスス \\
\hline
\end{tabular}

○わが国で作成したもの 
3 ）国際化学物質安全性カードーInternational Chemical Safety Cards, ICSCs

化学物質の製造，使用に携わる現場の人向けに書か れたもので，製造，使用，廃棄に際して注意すべき事 項を表裏 2 ページのカラー刷り一枚のカードにまとめ たもの。1990年発行を開始し，まず78枚のカードが刊 行された。年間200〜300カードを作成する予定で計画 は進んでいる。わが国でも年間20物質のカード作成を 行っている。対象は化学物質の製造, 使用, 廃棄に携 わる現場の監督者である。

4) 食品添加物，食品中の残留農薬，食品中の残留 動物薬に関するモノグラフーWHO Food Additives Series, FAO Plant Production and Protection Paper

IPCS は，FAO との協力によって200種以上の食品 添加物, 食品污染物質, 成長促進剂の許容一日摂取量 (ADI) 設定するための評価や再評価を行ってきた。ま た140種の農薬について評価を行い食品中の残留基準 を設定している。 $\mathrm{EHC} 70^{33}$ はわが国を含む54名の専門 家が参画し作成されたもので邦訳もされている。

\section{2 方法論の開発}

化学物質のヒトの健康と環境に及ぼす影響に関する 国際的に通用する試験法およびその評価，あるいは影 響予測に必要な原則や試験法の開発を促進している。

表 1 の網掛けをした11冊の出版物が方法論開発の成果 である。わが国も発癌物質の短期検索手法の開発, 卜 キシコカイネティクスについての評価法の開発, 免疫 毒性の試験方法の開発などに協力した。現在もバイオ マーカー (Biomarkers) や環境複合混合物中の生物活 性の評価 (The assessment of biological activity in environmental complex mixtures) 等の方法論につい て検討されている。

\section{3 中毒の予防と治療}

1989年 3 月西ドイツのハノーファーで開催された IPCS の会議に筆者が出席した際，インドのカンジー 医科大学の Misra 博士が1984年 Bhopal で起きたユ ニオンカーバイトのメチルイソシアネート (methyl isocyanate）による事故およびその後の住民の胸部障 害についてスライドを用いて詳細にその惨状を解説し てくれた。真夜中に事故が発生し，戸外で眠っていた ヒトが激しい眼刺激と呼吸障害で 900 名が急死し，さら に病院で処置を必要とした者が17万名にも達した。本 化合物に対する物理化学的性質や健康影響および適切 な応急処理方法等の適切な情報が会社からも文献情報 からも入手できない現場の医師として極めて困惑状態 にあった状況を博士は詳細に説明した。もし本化合物 の解説書が出版されていれば被害はもっと少なかった
のではとの思いを強くし IPCS の業務の重要性を痛感 した次第である。IPCS は the World Federation of Clinical Toxicology Centres and Poison Control Centres と共同して中毒の予防と治療に当っている。

\section{4 化学物質の安全性対策における人枋の教育訓} 練

\section{5 技術援助}

WHO には 6 つの地域事務所 (Regional Office for Africa, the Americas/PASB, South-East Asia, Europe, Eastern Mediterranean, and the Western Pacific）がある。わが国はマニラに事務所を持つ西太 平洋事務局 (WPRO) を通して化学物質の安全性に係 わる協力関係を持っている。WPRO は1977年 PEPAS (Promotion of Environmental Planning and Applied Studies) を環境計画やその応用研究の機関としてクワ ラルンプールに設立した。現在はIPCS，WPRO, PEPAS とわが国が協力して IPCS の化学物質の安全 評価，管理，取り扱い等に関する文書を有効利用する ことを目的として，各国語への翻訳およびこのような 文書を広めるためのネットワーク作りなどが急務であ るとの認識に立って計画を進めている。

\section{EHC 作成の過程における国際協力}

IPCS の活動の中で最も歷史があり，重視されてい るものが $\mathrm{EHC}$ である。最近筆者も WHO の飲料水水 質ガイドライン改訂作業でアクリルアミドの原稿作成 作業に参画したが, $\left.\mathrm{EHC} 49^{4}\right)$ は非常に役に立った。そこ で $\mathrm{EHC}$ 作成の経過での国際協力について表 2 を参照 しながら紹介したい。現在筆者が第一次ドラフトの作 成作業で担当しているものの一つにアセトニトリル (Acetonitrile) があり，わが国の研究者の協力を得て 完成しつつあるが環境生物への影響については英国の 環境科学者の協力を仰いでいる。次の段階である 「IPCS ネットワークを通じて各国供覧」はわが国でも 11カ所で行われている。最近一年間でも1,1,1-トリク ロロエタン (1,1,1-trichroroethane) を始め10種の化 学物質のドラフトについてコメントを提供し国際協力 を行っている。第 2 次ドラフトが完成するとタスクグ ループ会議が開催される。筆者の出席したジメチルホ ルムアミド（表 1，EHC114）の会議では IPCS の他に 国際癌研究機関 (International Agency for Research on Cancer, IARC) の研究者や米国，英国，ブルガリ ア，ベルギー，インド，クウェート，中国等の科学者 が出席しそれぞれの専門分野を中心に最終ドラフトを 完成させた。このように大きく分けると 3 段階になる それぞれのステップで国際協力を行っている。 
表 2 EHCドラフト作成経過と所要期間

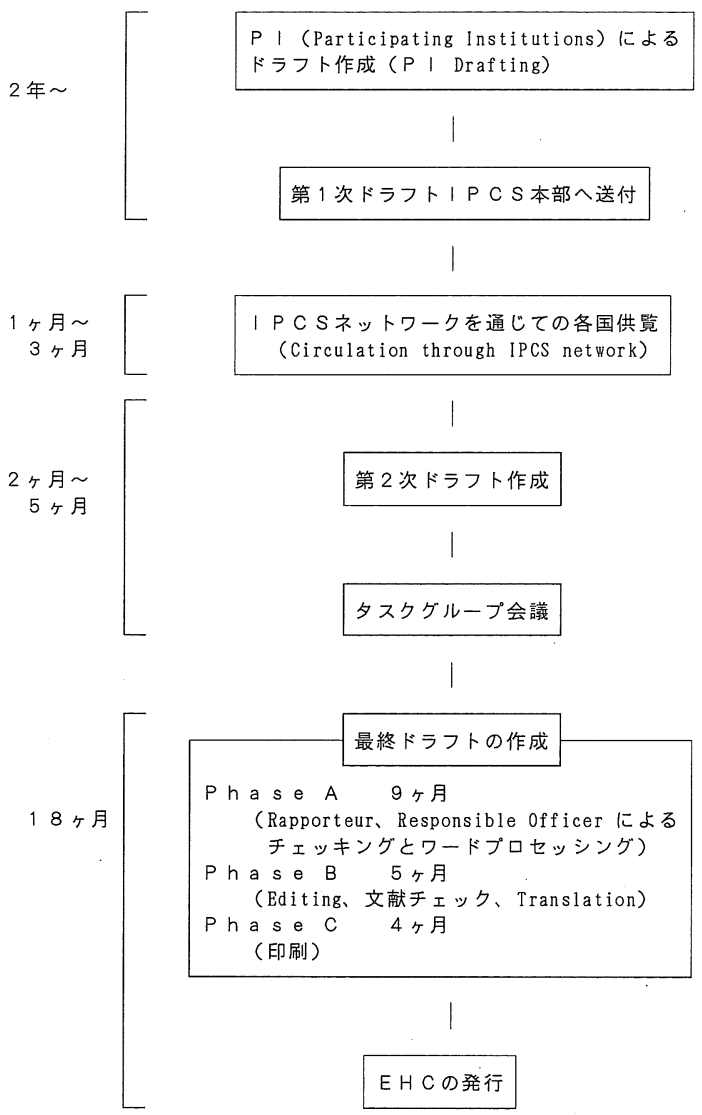

\section{EHC ドラフト中での環境に関する記述項目}

$\mathrm{EHC}$ のスタイルも何度かの執筆規定の改訂を経て， 表 3 のようなスタイルになっている。すなわち $3 ， 4$ ， $5 ， 7$ 章が環境に関するデータである。本誌の性格か ら環境に関する記述項目を紹介すると，

3 章 ヒトならびに環境の曝露源

3.1 天然中の存在

3.2 人為的污染源

3.2 .1 生産量と製造工程

一世界での生産量, 通常の製造工程での環境への移 行, 輸送方法, 事故による漏出, 廃棄物の処理法

3.2 .2 用途

一用途 (産業界, 一般市民), 使用範囲 (地域的, 世 界的)，規制の有無，使用の形態(単品，混合物，製

品)

4 章 環境中の移動, 分布, 変換

4.1 環境媒体中の移動と分布

一空気，水，土壤，植物と野生生物，食物連鎖中へ
表 3 環境保健クライテリア (EHC) ドキュメントの内容

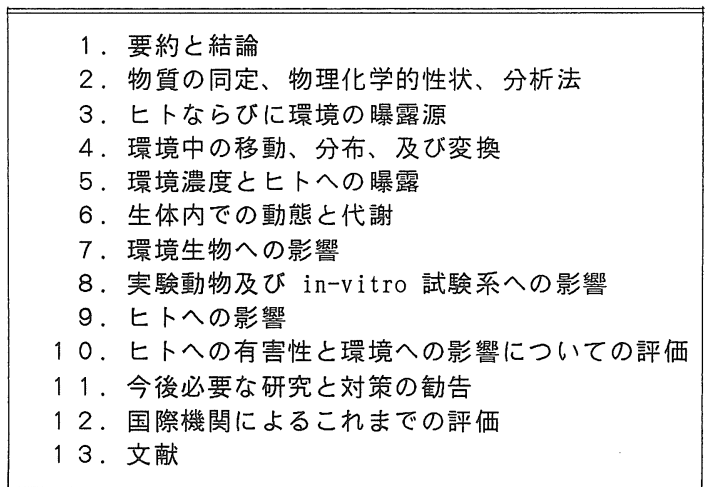

の導入

\section{2 生物学的変換}

一生分解, 非生物学的変換, 生物蓄積, 生物濃縮

4.3 その他の物理的, 化学的, 生物的諸因子との相 互作用

4.4 使用後の究極的な運命(廃棄に関する情報を含 む)

5 章 環境濃度とヒトへの曝露

5.1 環境中濃度

一空気，水，土壤，食物，飼料，夕バコなどのその 他の製品，陸生生物と水生生物

\section{2 一般市民への曝露}

一環境からの曝露, 食物, 飲物(飲料水を含む)，危 険度の高い特定の集団（新生児や幼児）

\section{3 職業嚗露}

7 章 環境生物への影響

7.1 微生物

7.2 水生生物

7.3 陸生生物

7.4 生物群と生態系への影響

7.5 非生物学的環境への影響

以上のように様々な環境動態に関する詳細な情報が 網羅されている。

\section{EHC の具体例としてのトリブチルスズ}

ごく最近到着した $\mathrm{EHC116のトリブチルスズ}$ (tributyltin compounds, TBT) について紹介すると， 226ページょり構成され,さらにフランス語とスペイン 語で「要約，ヒトへの有害性と環境への影響について の評価，および今後必要な研究と対策の勧告」が添付 され総ページは273ページとなっている5)。本文におけ る「環境生物への影響」の部分は76〜147ページとほぼ 3 分の 1 を占め, 水生生物への影響が詳細に記述され ており，第 1 次ドラフトを作成した英国の Institute of 


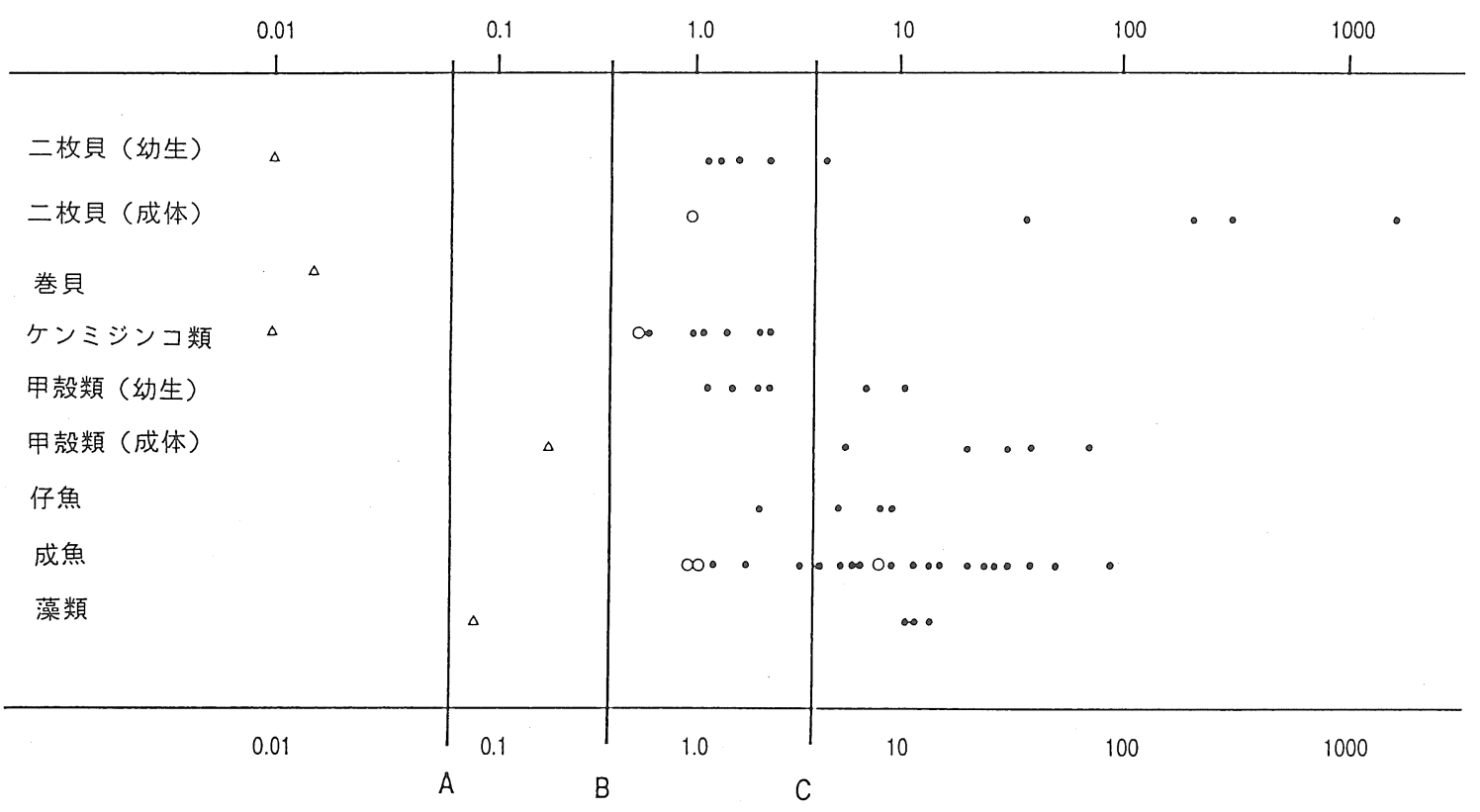

図 2 TBTの海洋生物への毒性 ${ }^{5}$

- $\mathrm{LC}_{50}$ (曝露後 96 時間以内)； $\circ \mathrm{LC}_{50}$ (曝露後96時間以上）： $\triangle$ 致死濃度以下の作用が出現する最低濃度 $\mathrm{A}=$ 外洋における最高濃度；B=入り江における最高濃度；C=港における最高濃度

Terrestrial Ecology の Dobson 博士の生態科学者と しての姿勢が執筆方針に反映されている。本化合物は フジツボや海藻類が船や魚網に付着するのを防ぐ上で 極めて有効なことから船底防污剤として船舶の塗料な らびに海洋農場における生物忌避剤として使用されて きたため, 海洋污染や海産物の污染が世界的な問題と なってきている。従って, 外洋, 入り江, 港の最も高 い濃度と水生生物に及ぼす毒性効果を $\mathrm{IC}_{50}$ で比較し ている。図 2 は 3 力国語に訳された要約の中に入って いる図であり, TBT が貝類, およびミジンコなどのケ ンミジンコ類に毒性が強いことがわかる。幼生のカキ (Crassostrea gigas) の無影響量 (No-observed-effect level, NOEL) は約 $20 \mathrm{ng} \cdot l^{-1}$ とされ，また成体の力キの 貝殼の奇形は用量に依存して起こり, NOEL は 2 ng・ $l^{-1}$ である。エビ (Acanthomysis sculpta) の生殖に対 する NOEL は90ng・ $l^{-1}$, また魚の $\mathrm{LC}_{50}$ 值は1.5〜36 $\mu \mathrm{g} \cdot l^{-1}$ と幅があり，仔魚の方が成魚より感受性が高 い。またトリブチルスズオキシド（TBTO）は $1 \mu \mathrm{g}$ 。 $l^{-1}$ 以上の濃度では魚に有害であるとしている。これら の評価文書が全世界に広く刊行され，WHO の揭げて いる『我々の地球 (Our Planet) そして我々の健康 (Our Health) をグローバルに考え (Think Globally)，地 域的に行動しょう (Act Locally)』が具体的な活動と
なることが期待される。

8.おわりに

国連人間環境会議から 20 年目を迎える1992年に，ブ ラジルで第 2 回の会議が開かれることになり，その準 備が現在急ピッチで進められている。IPCS も会議に 向けての化学物質の安全性管理のための国際機構とし て, 化学品規格計画委員会 (Codex Chemicalis Commission)の設立を考え準備委員会を開いている。21世 紀に向けて化学物質の安全性評価に関する国際協力と 情報管理は IPCS を中心として益々その重要性が増大 するものと考えられる。

\section{文献}

1) IPCS (1990) Ten years of chemical safety 1980-1990, 10pp., WHO, Geneva.

2) IPCS (1989) The WHO Envionmental Health Criteria Series, 30pp, WHO, Geneva.

3 ) IPCS (1987) Environmental Health Criteria 70 : Principles for the safety assessment of food additives and contaminants in food, 174pp., WHO, Geneva.

4) IPCS (1983) Environmental Health Criteria 49 : Acrylamide, 121pp., WHO, Geneva.

5) IPCS (1991) Environmental Health Criteria 116 : Tritutyltin compounds, 273pp., WHO, Geneva. 